\title{
MENCARI NILAI-NILAI TEOLOGIS DI BALIK LAGU "WE ARE THE WORLD" Suatu Kajian Teologi dan Budaya Populer
}

\section{Jelfy Lordy Hursepuny}

\begin{abstract}
Indonesia Churches have patent songs in their worship generally. With their songs are standard then other songs have no used again. Even though many songs such standard that theology should be reexamined. The Writer examines one of the popular song "We Are The World", by using the Correlational Revised approach that published by Tracy and Browning. The fact is these songs have in value solidarity and liberation that become the responsibility of the church of all time. The Church can be tolerant to the songs of popular that has the same vision to the struggle of the church.
\end{abstract}

Keywords: theology, culture, song and values

\begin{abstract}
Abstrak
Gereja-gereja di Indonesia pada umumnya memiliki lagu-lagu baku dalam peribadatan mereka. Dengan adanya lagu-lagu baku tersebut maka sering lagu-lagu di luar lagu-lagu tersebut tidak mendapat tempat sama sekali. Padahal banyak lagu-lagu baku tersebut yang teologinyaperlu dikaji ulang. Penulis mengkaji salah satu lagu 141opular "We Are The World", dengan menggunakan pendekatan Revised Correlational yang ditawarkan Tracy dan Browning. Ternyata lagu-lagu ini justru menawarkan seruan solidaritas dan pembebasan yang konon merupakan tugas gereja sepanjang masa. Gereja kemudian dapat bersifat lebih terbuka terhadap lagu-lagu budaya 141opular yang sevisi dengan perjuangan gereja.
\end{abstract}

Kata kunci : teologi, budaya, nyanyian dan nilai-nilai

\section{Pengantar}

Salah satu hasil keputusan persidangan Sinode GPIB yang diadakan di Pangkal Pinang provinsi Bangka-Belitung tanggal 18-21 Februari 2014 adalah, selama kegiatan ibadah berlangsung tidak diperkenankan bertepuk tangan. ${ }^{1}$ Keputusan ini mengundang diskusi ramai pada jejaring sosial facebook di 
kalangan rohaniwan GPIB. Menurut Margie Ivon dalam diskusi itu, konon bahwa keluarnya keputusan ini didasarkan pada hasil penelitian tim LITBANG GPIB bahwa persoalan terbesar GPIB adalah perjumpaan dengan Islam dan gerakan kharismatik. ${ }^{2}$ Menurut E. G. Singgih, ketika salah satu petinggi GPIB hadir dan beribadah di GPIB Margomulyo-Yogyakarta, jemaat bertepuk tangan setelah Paduan Suara menyanyi, ia melarangnya, sebab menurutnya tepuk tangan adalah untuk manusia bukan untuk Tuhan. ${ }^{3}$ Joseph Hehanusa juga mengatakan, GPIB ini ada-ada saja, tepuk tangan dipersoalkan, sementara isu-isu ketidakadilan dan kemanusiaan tidak dipikirkan dengan serius. ${ }^{4}$ John Simon, mengutip pernyataan E. G. Singgih bahwa yang tetap terasa sulit dalam tubuh Protestansime bahwa iman Kristen terdiri dari berbagai macam teologi, akibatnya mutlak-mutlakan dan merasa diri pihak yang paling benar. ${ }^{5}$

Mungkin pertanyaan yang patut diajukan adalah mengapa ada keputusan demikian? menurut yang telah disebutkan di atas, ini adalah salah satu cara untuk menghadapi gerakan kharismatik sebagai salah satu permasalahan besar yang menjadi pergumulan GPIB. Jika memang demikian, maka bisa dikatakan bahwa GPIB tidak biasa dalam bertepuk tangan di gereja, sementara gereja-gereja kharismatik biasa dalam bertepuk tangan. E. G. Singgih sendiri menegaskan, bahwa ia berasal dari tradisi gereja yang tidak bertepuk tangan, tetapi ia tidak seekstrim keputusan GPIB yang melarang bertepuk tangan dalam beribadah dengan mengambil contoh dari mahasiswa-mahasiswa teologi UKDW yang sering bertepuk tangandalam ibadah kampus. ${ }^{6}$

Saya tidak ingin berkomentar terlalu jauh terhadap persoalan "tepuk tangan" ala GPIB sebagaimana dikemukakan sebelumnya. Tetapi dari contoh GPIB tersebut, ternyata persoalan datang dan beribadah kepada Tuhan menjadi menjadi soal yang pelik. Tradisi menjadi dasar pijak bagi tata aturan dalam beribadah. Dalam contoh-contoh yang lain, tidak hanya tepuk tangan yang dipersoalkan tetapi lagu-lagu yang dinyanyikan dalam ibadah juga diperosoalkan. Yang boleh dinyanyikan hanya lagu-lagu yang sudah disahkan seperti Kidung Jemaat, Pelengkap Kidung Jemaat, dst. Yang lain dari itu tidak boleh dinyanyikan, karena teologinya tidak bisa dipertanggungjawabkan. 
Lagu-lagu yang menjadi warisan tradisi gereja-gereja tua di Indonesia justeru dalam beberapa hal sangat pietis. Sebagai contoh, (1). Nyanyian Dua Sahabat Lama no. 52 dan 63 misalnya, .../ku nanti akan Dikau/ dan api yang kudus, -...kesanalah kau rindu dendam. (2). Dua Sahabat Lama no. 98, ke rumah tempat yang senang/di mana tidak lagi perang. Teologi nyanyian-nyanyian ini justrumempromosikan tentang, surga, kedatangan Tuhan dan penghakiman kekal. Umat diajak untuk berpikir tentang "surga", kehidupan ini berkiblat ke sana. Otomatis hidup sekarang menjadi tidak penting, karena yang dipikirkan hanya hidup nanti di surga. Saya tidak bermaksud menyalahkan teologi yang ditawarkan nyanyian-nyanyian ini, tetapi unsur negatif yang harus dihindari adalah soal mengajak umat untuk berkiblat surga. Mungkin dalam hal ini, kritik Marx terhadap agama ada benarnya juga, agama sebagai opium atau candu masyarakat, ${ }^{7}$ membuat masyarakat tidak berpikir tentang pembebasan, karena agama meninabobokan masyarakat, kerja saja upahmu besar di surga.

Permasalahan sekarang adalah nyanyian-nyanyian warisan kolonal ini menjadi semacam "tradisi" yang dipegang kuat di dalam gereja-gereja tua ini. Otomatis nyanyian-nyanyian dari gereja saudara, dinilai sebagai yang tidak teologis. Kalau memang nyanyian dari gereja saudara tidak teologis atau tidak sesuai dengan warisan teologis gereja-gereja tua di Indonesia, bagaimana jika pertanyaan demikian: apakah nyanyian-nyanyian warisan gereja-gereja tua di Indonesia mempromosikan pembebasan atau melanggengkan status quo? agaknya ya, jika merujuk kepada contoh nyanyian-nyanyian yang telah disebutkan di atas.

Lagu-lagu rohani saja diklasifikasi sebagai yang searah atau tidak searah dengan tradisi gereja tertentu, bagaimaana dengan lagu-lagu yang sekuler atau non-rohani yang merupakan lagu produk budaya populer? penyanyi tenar Amy Grant's diperhadapkan dengan persoalan ini. Kesuksesannya di tahun 1980 dengan membawakan lagu "Sing Your Praise the Lord" membawa kesuksesan bagi bisnis musik injil, tetapi kemudian ketika mengeluarkan album "baby, baby" (1998), ia dikritik oleh kaum evangelikal sebagai yang tidak injili. Menghadapi kecaman ini, ia mengatakan dua pertanyaan yang menarik untuk dilihat. Pertama, orang sering menaruh musik injil pada sebuah kotak, tetapi Allah lebih dari pada 
itu. Kedua, yang namanya musik injil adalah tidak selalu dengan mengatakan "Yesus, Yesus". 8

Pernyataan Amy Grant ini menjadi titik tolak bagi saya untuk mengkaji lagu "We are the World", untuk menemukan nilai-nilai teologis seperti apa yang terkandung di dalamnya. Ada beberapa hal menjadi alasan mengapa saya mengkaji lagu ini. Pertama, sebagaimana persoalan boleh atau tidaknya bertepuk tangan persoalan lagu-lagu teologis dan tidak teologis menjadi persoalan serius di gereja-gereja saat ini. Di sini lagu-lagu sekuler yang adalah produk budaya populer bisa menjadi alternatif, bukan dalam arti menggantikan nyanyiannyanyian resmi di atas, persoalnya bukan lagi pada nyanyian mana yang teologis dan tidak teologis,mana nyanyianyang sesuai dan tidak sesuai, tetapi nyanyian yang sekuler pun bisa justru lebih teologis dari pada nyanyian resmi gereja.Bandingkan misalnya puisi-puisi W. S. Rendra yang terkenal itu, justru ia yang tidak mengecam pendidikan teologi, tetapi karya-karyanya sangat teologis. Kedua, oleh banyak gereja diklaim bahwa budaya populer sering menjadi ancaman bagi gereja-gereja dalam pemberitaan injil padahal di masa kini yang oleh Tapscot disebut sebagai net-generation ${ }^{9}$ ketika internet menjadi model komunikasi global, gereja tidak bisa lagi mengurung diri dalam gedunggedungnya, gereja harus bergerak keluar menjumpai dunia dalam tantangan dan kepelbagaiannya dari pada sekedar mengatakan bahwa budaya populer adalah ancaman bagi eksistensi bergereja. Tentu perjumpaan ini bukanlah tanpa kritik, budaya popular tentu dilihat dalam terang etis-teologis, bisa saja menjadi mitra dalam memberitakan injil Kerajaan Allah. ${ }^{10}$ Dalam bahasa Detweiler dan Taylor, mengkomunikasikan injil saat ini tidak hanya dengan memanfaatkan lagu-lagu rohani, tetapi para pendeta dan rohaniwan juga harus berpikir kreatif, menemukan kreativitas itu termasuk dalam budaya pop. ${ }^{11}$ Atau menggunakan bahasa Lynch, ada saling belajar di antara budaya kontemporer dengan tradisi religius. ${ }^{12}$

\section{Analisa Lagu "We Are The World"}

Dalam menganalisa lagu ini, saya menggunakan analisa literer, sebuah analisa yang dikenal umum dalam dunia sastra untuk mengkaji teks-teks sastra. 
Karena teks yang dianalisa merupakan sebuah lagu, saya juga memperhatikan dengan seksama bait demi bait yang membentuk lagu ini secara keseluruhan. Lagu "We Are The World" dapat saya sajikan sebagai berikut:

There comes a time

When We Head a certain call

When the World as come together as one

There are people dying

And its time to lend to life

The Greatest gift of all

We cant go on

Pretending day by day

That someone somewhere will soon make a change

We are all a part of

Gods great big family

And the truth you know love is all we need

Reff:

We are the world

We are the children

We are the ones who make a brighter day

So lets start giving

There a choice we're making

We're saving our own lives

Its true we'll make a better day just you and me

Send them your heart

So they'll know that someone cares

And their lives will be stronger and free

As God has shown us by turning stone to bread

So we all must lend a helping hand

When you're down and out

There seems no hope at all

But if you just believe

There's no way we can fall

Well, well, well, well, let us realize

That a change will only come

When we stand together as one 


\section{II.1. We are the World sebagai produk budaya populer}

Budaya popular dalam segala bentuknya memerlukan pendengar masal yang tercipta melalui urbainsasi dan demokratisasai dalam kaitan dengan teknologi distribusi masal. ${ }^{13}$ Gordon Lynch ${ }^{14}$ dengan mengikuti Storey, melihat bebepa hal penting budaya populer sebagai lawan high culture, atau dalam kaitan dengan high culture, juga sebagai sebuah bentuk sosial dan resistan kultural terhadap budaya dominan dan budaya masa. Jika mengikuti pertimbanganpertimbangan tentang definisi budaya populer ini maka, segala produk lagu, film, TV, fashion, selebriti, olahraga, dst yang dikenal dengan perantaraan media massa bisa diklasifikasikan sebagai buadaya populer atau produk-produk budaya populer.

Lagu karya Michael Jackson dan Lionel Richie ini dibuat untuk menggalang dana dalam membantu penduduk Etiopia di tahun 1984-1985. Bantuan ini dirasakan mendesak di waktu itu, karena PBB juga masih sibuk menanggulangi bencana serupa yang terjadi di beberapa negara , antara lain Mali, Nigeria, Sudan dan Mozambik. ${ }^{15}$ Lagu ini terinspirasi oleh "Do They Know its Christmas" dari Band Aid (anggota-anggotanya antaralain Bono, Phil Collins). Yang menjadi produser lagu ini adalah Quincy Jones dan Michael Omartian. Penyanyi Callipso, Belafonte pertama-tama yang mengadakan konser untuk musisi kulit hitam, kemudian Linoel Richie bergabung dan puluhan artis lainya turut terlibat. Uang yang didapatkan dari single ini sekitar 60 juta dolar dan langsung disalurkan ke Etiopia. ${ }^{16}$

\section{II.2. Analisa isi lagu "We are the World"}

Lagu "We are the World" ini atas lima bait, tiap baitnya terdiri dari 5-8 (bait satu dan dua berjumlah 6 baris, reff berjumlah 8 baris, bait empat dan lima masing-masing berjumlah lima dan tujuh baris baris, jadi jumlah baris per baitnya jika dipolkan 6-6-8-5-7 totalnya 32 baris baris). Jika dinyanyikan dengan bait pertama dan kedua sebagai bait pembuka lalu ke reff (bait ketiga) kemudian bait 
keempat, kembali lagi ke reff, lalu bait kelima dan kembali lagi ke reff sekaligus diakhiri.

Bait pertama dibuka dengan "there comes a time", digunakan bentuk waktu present pada kata kerja "come": dengan sufiks "s" dibelakangnya, hendak menunjukkan bahwa "waktu itu adalah sekarang, bukan nanti atau dulu, sedang tiba waktunya. Baris kedua menjelaskan keadaan presentis dari waktu tadi, "When We head a certain call'. Subyek yang digunakan di sini adalah "we" (kami atau kita), siapakah mereka? dari latar belakang lagu yang di segera disampaikan di atas bisa dimengerti bahwa Michael Jackson dan Lionel Richie bersama dengan deretan artis sedang berupaya menggalang dukungan dana bagi para penduduk Etiopia yang mengalami musibah kekeringan. Menarik bahwa apa yang mereka lakukan itu coba diyairkan dengan "a certain call' sebuah istilah yang sarat dengan nuansa teologis. Usaha untuk membantu korban kekeringan di Etiopia tidak hanya sebuah bantuan semata, tetapi sebuah panggilan, panggilan untuk membantu. Kata kerja "head' yang berarti memimpin atau mengorganisasi juga memperlihatkan bahwa subyek"we" tidak terbatas pada Michael Jacson dkk, tetapi Jackson dan kawan-kawan sementara menggorganisasi sebuah panggilan yang menuntut respons dari para pendengarnya. Panggilan yang dimaksud adalah panggilan untuk dunia, "when the world as come together as one", dunia berkumpul bersama atau bersatu untuk merespons musibah kekeringan itu. Baris keempat lebih menspefikasikan alasan mereka, dimensi presentis dari lagu ini begituditekankan, atau mengapa dunia harus bersatu merespon panggilan itu, "There are people dying". Fakta kematian/kedukaan menjadi alasaan bagi dunia untuk merespon panggilan, memang tidak disebutkan secara langsung siapa yang mati (latar belakang lagu bisa secara langsung menunjuk kepada korbankorban kekeringan di Etiopia) tetapi dengan alasaan kematian, ini alasan kemanusiaan, yang tentu mengundang orang untuk berempati. Baris keempat, segera diikuti dengan baris kelima, "and its time to lend to life", merespons kematian adalah dengan memberi kehidupan, dan baris penutup dari bait pertama ini ditutup dengan "the greatest gift of all", baris penutup bait ini coba 
melanjutkan bait lima bahwa kehidupan itu sendiri adalah anugerah terbesar bagi semua orang.

Bait kedua dimulai dengan "we cant go on, pretending day by day", dua baris digabungkan di sini karena merupakan satu kesatuan, "kita tidak bisa terus menerus berpura-pura dari hari ke hari”, menurut hemat saya syair ini ditampilkan untuk menggugah pendengar dalam membantu korban kekeringan Etiopia sebagai konteks yang melatari lagu ini. Penempatannya pada bagian awal bait kedua juga meneruskan ide "memberi untuk kehidupan" yang ada pada bait satu di atas. Orang agaknya belum begitu tergerak untuk memberi, dan ungkapan dari barisbaris begitu menggugah, melihatnya sebagai "kepura-puraan", mengapa? karena kehidupan yang sementara diperjuangkan di sini.

Baris selanjutnya "that someone, somewhere will soon make a change", berfungi sebagai undangan untuk memberi, dan undangannya itu bisa kepada siapa saja untuk telibat sebagaimana ditunjukkan dengan kata "somewhere", untuk segera membuat sebuah perubahan, bergerak dari kepura-puraan atau sikap masa bodoh atau bukan urusan kita untuk membuat sebuah perubahan. Mengapa perubahan itu begitu mendesak (soon) dan perlu? jawabannya ditemukan pada baris empat dan lima dari bait kedua ini "We ara all a part of/Gods great big family", sebagai bagian dari keluarga besar Allah. Undangan untuk membuat perubahaan diberi sebuah afirmasi teologis bahwa kita semua adalah bagian dari satu keluarga Allah yang besar. Persoalan membuat perubahan dalam arti memberi diletakkan dalam kerangka memberi di antara sesama anggota keluarga Allah. Bait kedua ini ditutup dengan "and the truth, you know love is all we need", kata kuncinya pada kata "love" bahwa yang dibutuhkan adalah "kasih". Undangan kepada yang memberi karena mereka mengetahui "kasih", bukankah "kasih" adalah landasan bagi sebuah keluarga Allah? ya, karena itu yang diperlukan sekarang.

Bait ketiga (dalam nyanyian berfungsi sebagai reff) atau bisa dikatakan juga sebagai klimaks lagi sebuah lagu, dalam nyanyian bentuk reff ini selalu dinyanyikan dengan tangga nada tinggi. Inti dari lagu ini terdapat di sini. Baris pertamanya berbunyi "we are the world", kita adalah dunia, baris kedua "we are 
the children", anak-anak segera menjadi fokus perhatian, dan dalam baris ketiga "we are the ones who make a brighter day", ditujukan secara khusus bagi para pendengar, dengan tampilmya subyek "kita". Sekali lagi hendak mengsabsah undangan lagu ini kepada siapa saja. Pada baris keempat dan kelima undangan mendapat bentuknya yang kongkrit "so lets start giving", baris yang kelima dan keenam berbunyi "there a choice we're making, "we're saving our own lives". Dengan menyebutkan "kita menyelamatkan hidup kita sendiri", mungkin berarti persoalan memberi dilihat dalam kerangka keluarga Allah. Dalam arti memberi antar sesama anggota keluarga Allah. Jika kehidupan itu menjadi sesuatu yang patut diselamatkan, maka kehidupan itu menjadi bagian dari hak semua orang, kita menyelamatkan kehidupan yang inheren menjadi bagian dari hak kita. Bait ketiga ini diakhiri dengan "its true we'll make a better day just you and me". Pilihan untuk menyelamatkan kehidupan, berarti "make a better day", membuat hari yang lebih baik dari yang sebelumnya, bagian ini juga bisa diparalelkan dengan baris ketiga di atas "make a brighter day", membuat hari lebih cerah.

Bait keempat dimulai dengan "send them your heart" sebagai baris pertama, diikuti dengan "so they'll know that somenone cares". Istilah "heart' menjadi penting untuk memahami dua baris awal bait empat ini, mengapa? hati selalu menjadi pusat dari emosi dan empati manusia, dan undangan memberi bantuan tidak hanya dilihat sebagai bantuan semata, tetapi nantinya wujud dari bantuan itu adalah wujud kepedulian. Memberi jangan setengah-setengah, atau jangan memberi dengan pura-pura, totalitas memberi dituntut dalam hal ini. Barisbaris selanjutnya berbunyi "and their lives will be stronger and free", "as God has shown us by turning stone", "so we all must lend a helping hand", merupakan tiga baris penutup dari baris empat. Kata Penghubung "and" yang berada di awal baris ketiga, menujukkan lanjutan dari baris kedua. Tetapi yang menarik di sini adalah pernyataan baris ke empat, "sebagaimana Allah telah menunjukkan kepada kita dengan mengubah batu menjadi roti', jelas bahwa pernyataan ini mengingatkan pembaca kepada kisah Yesus dicobai dalam kisah-kisah Injil. Tetapi, yang menjadi penekanan narasi-narasi Injil adalah, bukan soal batu diubah menjadi roti, tetapi manusia tidak hanya hidup dari roti saja, tetapi dari firman yang keluar dari 
mulut Allah. Ternyata memang benar, ada kesalahan pengutipan di sini. Behind the scene ini menunjukkan bahwa Willi Nielson yang menyanyikan lagu ini ternyata salah memahami maksud Matius 4 (kisah pencobaan Yesus). ${ }^{17}$ Walaupun ada kesalahan pengutipan di sini, penempatan baris yang salah kutip ini agaknya menegaskan maksud bait ini dalam rangka teologis, membantu korban kekeringan dilihat dalam rangka memberi dengan hati, tetapi juga meneruskan apa yang dulu telah telah Allah (has shown) buat "mengubah batu menjadi roti".

Baris kelima sebagai baris penutup lagu ini empat baris awlanya agaknya ditujukan bagi yang mengalami bencana kekeringan. Baris-barisnya dengan jelas menunjukkan hampir tidak ada lagi harapan, keadaan down dan out, dan tidak ada lagi jalan. Tetapi tiga baris terakhit berusaha untuk membalikan keadaan tadi menjadi sebuah harapan, dan perubahan itu bisa terjadi ketika kita datang sebagai suatu kesatuan. Keadaan tidak ada harapan diatas justru diatasi dengan meminta semua orang (we), untuk "stand together", beban itu dipikul secara bersama-sama. Ketika orang bahu-membahu, bersama-sama untuk menanggung sebuah beban, ini jelas sebuah kekuatan.

\section{II.3. Nilai-nilai teologis "We are the World"}

\section{Memberi kehidupan}

Lagu yang diciptakan oleh Michael Jackson dan Lionel Richie di tahun 1985 untuk menolong korban kekeringan di Etiopia di waktu itu. Walaupun lagu ini diciptakan demi kegiatan amal, tetapi syair lagu tersebut sarat dengan makna teologis. Dalam bait pertama, Jackson dan Richie yang berusaha menggalang dana lewat lagu ciptaanya itu melihatnya sebagai sebuah panggilan. Mereka sementara mengakomodir bantuan dana untuk Etiopia, tetapi melihatnya sebagai sebuah "panggilan", panggilan iman jika mau dibahasakan. Yang diperjuangkan di situ, adalah "kehidupan", sebagaimana kata "dying" pada baris ke empat bait satu diparalelkan dengan "life' pada baris kelima. Kehidupan yang sementara diperjuangkan di sini, kehidupan dari korban kekeringan Etiopia. Bukankah usaha untuk melawan kematian dan memperjuangkan kehidupan juga bagian dari usaha 
berteologi? saya menjawab ya, dan inilah salah nilai yang yang terkandung dalam lagu ini.

\section{$>$ Memberi sebagai satu keluarga Allah}

Mazmur 133 berbicara tentang persaudaraan yang rukun, tetapi syair ini membicarakan tentang memberi sebagai satu keluarga Allah. Dunia yang terdiri beragam ini dilihat sebagai bagian dari satu keluarga Allah. Itu berarti, ada batas yang bisa direlativisir di antara pemberi sumbangan dan yang menerima sumbangan, karena memberi di sini dilihat sebagai pemberian antara sesama anggota keluarga. Mereka yang diperjuangkan oleh Jackson dan Richie untuk dibantu adalah anggota-anggota keluarga Allah. Jika ada salah satu anggota keluarga menderita kedukaan atau bencana, anggota keluarga mana yang tidak sedih atau berempati? dengan melihat masalah kekeringan Etiopia dalam bingkai kesulitan salah satu anggota keluarga Allah, Jackson dan Richie berusaha mencuri perhatian dan empati pendengarnya.

\section{$>$ Memberi dengan hati}

Mengasihi Tuhan dan sesama dengan segenap hati adalah hukum yang terutama dari Taurat. Begitulah yang dikatakan oleh Tuhan Yesus. Justru membantu korban keeringan di Etiopia diletakkan Jakcson dan Richie dalam kerangka hukum ini. Walaupun tidak disebutkan secara langsung, tetapi implisit bisa ditemukan pada baris pertama bait ke empat syair ini. Persoalan membantu adalah persoalan kepedulian dan kepedulian itu hanya akan diketahui jika pemberian itu didasarkan dengan hati, yang dibahasakan penulis di sini dengan “memberi dengan hati”. Kembali Jackson dan Richide berusaha untuk menggugah pendenganrnya. Jika membeir dengan hati yang diharapkan di sini, justru ini sangat teologis. Hati yang adalah pusat dari rasa dan empati manusia sebagaimana yang menjadi ciri ungkapan-ungkapan biblis. Totalitas dalam memberi diharapan di sini, sebagaimana hati menjadi pusat dari empati manusia. Merasakan derita korban kekeringan Etiopoa, berarti, mengasihi mereka dengan segenap hati. 
Apalagi persoalan memberi dengan hati ini dihubungkan dengan memberi sebagai sesaman keluarga Allah, sungguh sarat makna teologis.

\section{$>$ God has shown us by turning stone to bread}

Bagian inilah yang secara eksplisit mengingatkan pembaca bahwa baris syair ini bersumber pada Alkitab. Tentu bahwa yang dimaksudkan adalah kisah pencobaan Yesus di padang gurun dalam Mat. 4:4, manusia hidup bukan dari roti saja tetapi dari firman yang keluar dari mulut Allah. Memang ada kesalahpahaman di sini (sebagaimana dijelaskan dalam bagian analisa isi lagu). Tetapi undangan untuk memberi di sini diberi afirmasi teologis, sebagaimana dulu pernah Tuhan juga buat, dengan mengubah batu menjadi roti, mengubah kematian menjadi kehidupan, maka orang-orang juga diminta untuk melakukan hal yang sama membantu korban kekeringan Etiopia, di tahun 1985, atau korban gempa Haiti di tahun 2005.

\section{Dialog "We are the World" dan "Teologi"}

Melengkapi lima tipologi Kristus dan Kebudayaan ala Niebuhr, ${ }^{18}$ Lynch menawarkan empatpendekatan yang bisa digunakan untuk menganalisa budaya populer. Dalam bahasa Lynch, melihat hubungan antara teologi dan budaya populer. Pertama, pendekatan aplikasionis. Dalam pendekatan ini, budaya populer menjadi pokok kritik dengan berlandaskan kepada nilai-nilai dan tradisi teologis. Asumsi dasar dari pendekatan ini adalah mengidentifikasi core teologis dari sumber-sumber kekristenan baik Alkitab dan tradisi dan menggunakan secara kritis untuk kepercayaan dan nilai-nilai budaya populer, apakah budaya populer itu negatif atau positif, sesuatu atau tidak sesuai dengan pandangan keagamaan. Walaupun suara dari budaya populer didengarkan tetapi akhirnya nilai dan norma teologislah yang menentukan perjumpaan. ${ }^{19}$

Kedua, pendekatan korelasional. Pendekatan ini dikemukakan oleh Paul Tilich. Bagi Tilich, teologi menjadi sebuah proses korelasi persoalan-persoalan yang ditimbulkan oleh kebudayaan kontemporer dengan jawaban-jawaban yang dinyatakan melalui tradisi religius. Sedikit lebih maju dari pendekatan 
aplikasionis, pendekatan ala Tilich ini cukup memperhatikan dimensi "conversation" di antara teologi dan budaya populer. Suara dari budaya populer juga lebih didengarkan melampaui pendekatan aplikasionois di atas. Budaya populer yang lebih luas dari gereja juga turut memberi sumbangan bagi pemahaman eksistensial. Pendekatan ini turut membuka kemungkinan bahwa budaya populer bisa memainkan peran yang penting dan konstruktif sebagai tambahan terhadap tradisi religius. ${ }^{20}$

Ketiga, pendekatan revised correlational. Pendekatan ini merevisi model kedua diatas dengan David Tracy dan Don Browning sebagai pelopornya. Satu tingkat lebih maju dari pendekatan korelasional di atas, pendekatan ini mengusung sebuah percakapan yang kompleks melibatkan pertanyaan dan jawaban mencakup baik tradisi dan kebudayaan. Dalam pendekatan ini, kebudayaan kontemporer bisa menjadi sebuah mediator kebenaran dan kebaikan, kebudayaan kontemporer bisa menghasilkan pemahaman dan menantang kita untuk merevisi, melihat kembali ide-ide yang sudah menjadi bagian dari tradisi religius. $^{21}$

Keempat, pendekatan praxis. Meneruskan apa yang menjadi ciri dari pendekatan revised correlational, tetapi dengan perbedaan yakni berkomitmen untuk mengkritik baik budaya populer dan tradisi relijius, apakah mempromosikan pembebasan ataukah tidak. Berbeda dengan model aplikasionis yang menimbang budaya populer dengan berdasar pada ortodoxi (ajaran yang benar), maka pendekatan ini berdasar kepada ortopraxis (dalam kapasitasnya mempromosikan tindakan yang benar). ${ }^{22}$

Menawarkan keempat pendekatan di atas, Lynch $^{23}$ sendiri cenderung kepada model pendekatan yang ketiga "revised correlational." Sebab menurutnya baik kebenaran dan kebaikan tidak hanya menjadi milik an sich tradisi religius semata. Unsur both dan anddengan jembatan percakapan menjadi ciri khasrevised correlational. Lynh meminjam istilah Seward Hiltner, teologi bisa dilihatsebagai "two way street" yang mana tradisi relijius dan kebudayaan kontemporer bisa salingbelajar satu sama lain. ${ }^{24}$ 
Saya hendak mengaplikasikan pendekatan revised correlational terhadap lagu We are the World ini. Karena percakapan di antara budaya kontemporer dengan tradisi relijius tidak bersifat searah tetapi dua arah, maka ada dua pertanyaan penting yang patut dijawab. Pertama, apa yang budaya populer pelajari dari tradisi religius? atau lebih tepatnya lagu We are the World punya pendasaran teologis apa? dalam analisa teologis telah dijelaskan panjang lebar tentang nilainilai teologis yang coba dirangkum berdasarkan isi lagu tersebut. Pencipta lagu ini tentu menjadikan tradisi imannya sebagai titik tolak untuk menyusun lagu ini. Eksplisit ataupun implisit ditemukan latar asumsi teologis yang menjadi latar belakang lagu ini. Secara implisit, gema dari hukum kasih menurut Mat.2:34-40 dan persaudaraan yang rukun menurut Mazmur 133 bergaung dalam syair ini. Secara eksplisit penyebutan baris "..by turning stone to bread", mengingatkan para pendengar Kristen bahwa yang dimaksudkan di sini adalah kisah pencobaan Yesus di padang gurun, menjadi latar bagi kemunculan baris ini. Walaupun adamis-understanding terhadap kisah pencobaan Yesus (sebagaimana yang telah dijelaskan dalam bagian analisa isi lagu) tetapi makna baris ini adalah jelas, membantu korban kekeringan di Etiopia berarti melakukan apa yang dulu telah Allah lakukan dengan membuat batu menjadi roti. Pada titik ini, lagu ini sarat dengan makna teologis. Jika kemudian tradisi religius dipakai sebagai norma untuk menilai, maka pada titik ini lagu ini sarat dengan makna teologis, atau mengusung nilai-nilai teologis yang telah menjadi warisan tradisi seperti kasih, keluarga Allah, dst.

Namun, pertanyaan kedua ${ }^{25}$ yang kemudian harus diajukan adalah apa yang tradisi relijius ini belajar dari budaya populer, atau lebih spesifik pertanyaannya gereja (tradisi mempelejari apa dari lagu We are the World? pertanyaan ini harus dijawab sebab inilah cara kerja dari pendekatan "revised correlational". Kembali kepada bagian pendahuluan di atas, lagu ini bisa menjadi semacam penyeimbang bagi lagu-lagu tua warisan gereja-gereja tua di Indonesia yang masih dipegang saat ini. Teologi lagu gereja-gereja ini masih berkiblat ke seberang dan memikirkan hal-hal yang transenden, sehingga kekinian hidup tidak lagi menjadi penting. Justru syair lagu ini berada pada kutub yang berseberangan dengan lagu- 
lagu di atas, sebagai penyeimbang lagu ini mengusung imanensi dan kekinian hidup. Para pendengar diajak untuk berpikir realitas kekinian, bukan surga yang di seberang sana. Dalam lagu-lagu warisan gereja-gereja tua, orang diajak untuk menemukan Tuhan di awan-awan, tetapi syair lagu ini mengajak orang untuk mengalami Tuhan kini dan di sini, dengan cara yang bagaimana? Membantu korban kekeringan Etiopia. Tuhan ditemukan dalam wujud uluran tangan yang bersedia membantu korban-korban kekeringan di Etiopia (atau korban gempa Haiti di tahun 2005). Pada titik ini mungkin Gereja harus kembali melihat ulang tradisi teologis yang berada di balik lagu-lagu resminya. Gereja belajar dari We are the World sebagai prdoduk budaya populer. Lagu yang mungkin saja tidak teologis karena berada di luar gereja, justru sangat teologis. Mungkin juga penting untuk mengaitkan hal ini dengan apa yang dikatakan oleh Hehanusa di atas, merespons persoalan tepuk tangan ala GPIB, bahwa masalah seperti ketidakadilan dan perdamaian itulah yang harus menjadi pergumulan teologis GPIB.

Dengan pendekatan praxis juga, lagu ini bisa dilihat, sebagai lagu yang mempromosikan liberation, berlawanan dengan lagu-lagu gereja-gereja tua yang pro-status quodi atas. Ya, karena kiblat ke surga tentu melemahkan daya kritis masyarakat yang di dalamnya gereja ada.Pengalaman historis telah membuktikan itu, bahwa lagu-lagu tua warisan gereja, yang kemudian bisa diklaim sebagai tradisi religus tanpa bisa diganggu gugat ternyata di masa kolonial dipakai untuk melanggengkan kolonialisme. Saya tidak punya data untuk mem-back up pernyataan ini, tetapi dari pengamatan sepintas saya terhadap lagu-lagu tua warisan gereja sebagaimana yang telah dijelaskan dalam bagian pendahuluan, ada kesan menghilangkan daya kritis masyarakat. Jika gereja mau berjuang melawan pergumulan ketidakadilan dan usaha perdamaian, hal pertama yang harus gereja lakukan adalah melihat kembali ulang teologi yang terkandung dalam lagulagunya, sebab bagaimanapun umat tentu terpengaruh dengan lagu-lagu itu.Atau jangan teologi lagu itu menjadi semacam ideologi yang membelenggu umat untuk tidak peka terhadap situasi kekinian karena hanya memikirkan keakanan (baca: surga). "Perubahan itu akan terjadi ketika dunia datang sebagai satu kesatuan", 
demikian dua baris terakhir lagu We are the World. Dengan kata lain bisa dibahasakan begini: perjuangan gereja untuk melawan ketidakdilan dan konflik, dan masalah-masalah mendesak yang lain akan sia-sia jika teologi tradisional (atau ideologi) yang diusung lagu-lagu tradisional dan resmi gereja tidak dilihat kembali.

\section{Kekuatan transformatif "We are the World"}

Gustavo Gutierez ${ }^{26}$, salah seorang teolog dari Amerika Latin dalam bukunya The God of Life mengingatkan bahwa penyembahan kepada berhala mengambil berbagai bentuknya saat ini dalam wujud berhala modern. Bukan saja di Afrika, tetapi di berbagai belahan dunia yang lain. Di satu sisi mengatakan taat kepada Tuhan tetapi pada sisi yang lain melayani mamon dengan cara pembunuhan dan penganiayaan terhadap orang miskin. Ini adalah lebih kepada bentuk penolakan kepada eksistensi Allah. Ia kemudian memperlawankan antara Allah kehidupan dan allah kematian. Allah kehidupan adalah Allah yang pro kepada kehidupan, berlawanan dengan mamon yang mewujud dalam strukturstruktur sosial yang menindas, dalam ketidakdilan, dan kekacauan. ${ }^{27}$ Tiga puluh dua tahun kemudian, pemikiran Guztavo Gutierez ini diakui sebagai tema sidang raya DGD yang diadakan di Busan-Korea Selatan, tahun 2013: God of life, Lead to Justice and Peace.

Jauh sebelum DGD mengusung tema Allah kehidupan yang bersumber dari Gustavo Gutierez, enam tahun sebelum Gustavo Gutierez mengeluarkan bukunya "God of Life" di tahun 1991, sudah sejak tahun 1985 Michael Jackson dan Lionel Richie menggunakannya dalam lagunya. Membantu korban kekeringan Etiopia tidak dilihat dalam rangkan bantuan sosial semata, tetapi memperjuangkan kehidupan berlawanan dengan kematian. Bukankah Allah kehidupan yang diusung oleg Gutierez dan DGD adalah Allah yeng juga berjuamg melawan kematian, mempromosikan kehidupan? ya, inilah yang dilakukan oleh Jackson dan Richie dengan syair lagunya. 
Ide-ide transformatif lagu karya Jackson dan Richie ini mengajak orang untuk mengalami Tuhan dalam kekiniannya, membantu korban bencana alam. Tuhan ditemukan tidak dalam keagungan-Nya tetapi Tuhan justru ditemukan ketika ada uluran tangan untuk membantu para korban, Tuhan justru dialami oleh orang-orang Etiopia ketika bantuan itu datang. Memberi bantuan kepada para korban kekeringan bencana dilihat dalam kerangka membantu sesama anggota keluarga Allah. Allah yang besar coba dibahasakan Jackson sebagai dalam ungkapan "keluarga Allah". Allah yang demikian tidaklah jauh tetapi Allah yang inheren dengan perjuangan manusia, perjuangan para korban bencana alam untuk tetap bertahan hidup. Dunia yang luas ini coba dipahami Jackson dan Richie dalam terang "keluarga Allah", Allah siapakah yang tidak bersedih ketika melihat anggota keluarganya mengalami bencana atau ketidakadilan? Dalam konteksnya, memang lagu ini ditujukan sebagai konser amal yang berusaha untuk membantu korban kekeringan Etiopia, tetapi teologi yang coba ditawarkan lagu ini berjalan melampaui usaha tersebut bahkan lebih. Inilah kekuatan transformatif lagu ini. Mungkinkah gereja terlambat menyadarinya, baru mengusung tema "Allah kehidupan" ini di tahun 2013? Mungkin.

\section{Penutup}

Dalam analisa yang telah dilakukan terhadap salah satu lagu produk budaya populer ini, terlihat dengan jelas bahwa pesan lagu tersebut justru membawa pesan yang juga digumuli oleh gereja. Pesan untuk solidaritas, kehidupan, dan pembebasan bagi semua orang. Gereja seharusnya bisa belajar dari lagu-lagu produk budaya populer ini. Secara internal, gereja perlu untuk mengkaji kembali warisan lagu-lagu kolonialnya apakah masih sesuai untuk saat ini ataukah tidak. Secara eksternal, ketika sebuah karya budaya populer menawarkan pesan pembebasan, gereja perlu untuk mendukungnya, tidak perlu bersikap skeptis, atau bahkan melarang jemaatnya untuk menyanyikan lagu-lagu tersebut dalam ibadahibadah. 


\section{Endnote :}

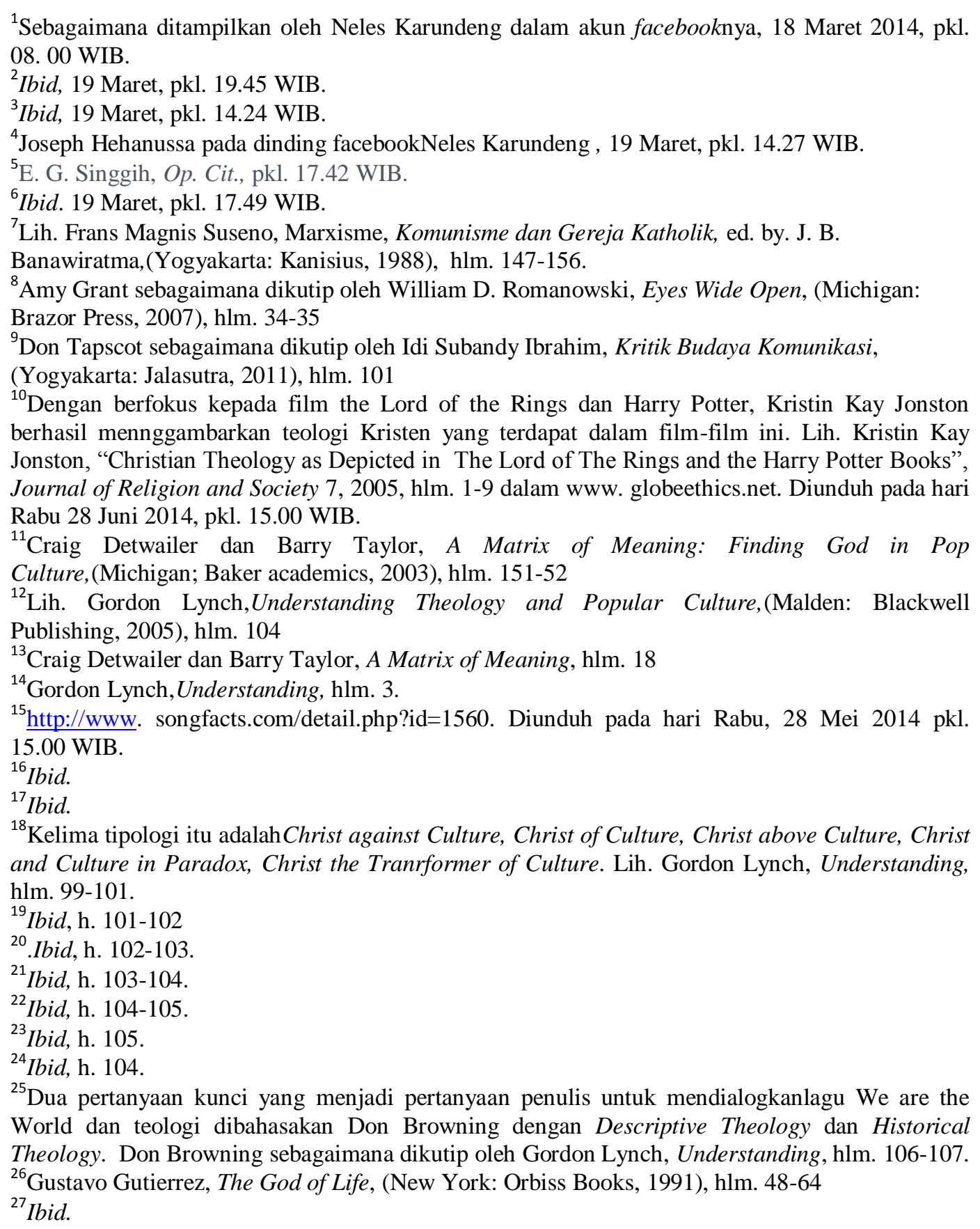

\section{DAFTAR PUSTAKA}

Schreuder. C. Ch. J dan I. J. M. Tupamahu, 1979. Dua Sahabat Lama.Tanpa penerbit. 
Detwailer, Craig dan Barry Taylor, 2003. A Matrix of Meaning: Finding God in Pop Culture.Michigan: Baker academics.

Ibrahim, Idy Subandy, 2011.Kritik Budaya Komunikasi. Yogyakarta: Jalasutra.

Jonston, Kristin Kay, "Christian Theology as Depicted in The Lord of The Rings and the Harry Potter Books",2005. Journal of Religion and Society 7, dalam www.globeethics.net.

Lynch, Gordon,2005. Understanding Theology and Popular Culture.Malden: Blackwell Publishing.

Romanowski, William D, 2007. Eyes Wide Open.Michigan: Brazor Press.

Schreuder. C. Ch. J dan I. J. M. Tupamahu, 1979. Dua Sahabat Lama.Tanpa penerbit.

Suseno, Frans Magnis, 1988. Marxisme,Komunisme dan Gereja Katholik.ed. by. J. B. Banawiratma, Yogyakarta: Kanisius.

Sumber Internet:

http://www. songfacts.com/detail.php?id=1560. Diunduh pada hari Rabu, 38 Mei 2014 pkl. 15.00 WIB. 